\title{
Analisa dan Perancangan Sistem Informasi Sales Order (SO) Berbasis Web dengan PHP SQL (Studi Kasus : PT. Abc Steel )
}

\author{
Anharudin \\ Program Studi Sistem Komputer Fakultas Teknologi Informasi Universitas Serang Raya \\ Jl. Raya Cilegon Serang Drangong Taktakan Kota Serang Banten Indonesia \\ anhar.dean@gmail.com
}

\begin{abstract}
Abstrak - Perusahaan sebagai organisasi yang memiliki kecenderungan orientasi pada laba, selalu membutuhkan sistem yang terkomputerisasi dalam mengumpulkan, menyimpan, dan memproses data untuk menghasilkan informasi yang dapat membantu perusahaan dalam melakukan perencanaan strategi dan pengambilan suatu keputusan secara efektif. PT. ABC Steel sebagai salah satu perusahaan baja yang berlokasi di kota Cilegon. Perusahaan telah menggunakan sistem manual dalam mendukung kegiatan usaha terkait sejak didirikan pada tahun 2000. Sistem manual telah menjadi masalah bagi perusahaan untuk menangani kegiatan harian bisnis terkait yang terus meningkat setiap tahun. Sehingga, perusahaan memutuskan menggunakan sistem komputerisasi. Beralihnya ke sistem komputerisasi akan meliputi tiga langkah: analisis, desain dan implementasi. Alat yang akan mendukung proses analisis sistem dan desain, sebagai berikut: Data Flow Diagram, ER-Diagram, Skema Database dan Pengguna Sketch Interface Design. Alat yang akan digunakan untuk mengimplementasikan sistem adalah PHP \& MySQL.
\end{abstract}

Kata kunci : PHP, SQL, Data Flow Diagram, ER-Diagram, Penjualan.

\section{PENDAHULUAN}

Perusahaan adalah tempat terjadinya kegiatan produksi dan berkumpulnya semua faktor produksi. Untuk menghasilkan barang siap pakai atau dikonsumsi, perusahaan memerlukan bahan - bahan dan faktor pendukung lainnya, seperti bahan baku, bahan pembantu, peralatan dan tenaga kerja. Untuk memperoleh bahan baku dan bahan pembantu serta tenaga kerja dikeluarkan sejumlah biaya yang disebut biaya produksi.

Secara umum kondisi industri baja di dalam negeri masih belum seimbang antara industri hulu dan hilir. Akibat keterbatasan industri baja hulu maka industri baja hilir dalam negeri masih sangat tergantung kepada bahan baku impor. Hal ini disebabkan tidak berkembangnya industri bahan baku baja lembaran yang kapasitas produksinya hampir tidak mengalami perubahan sejak 2004.

Sebagai gambaran, berdasarkan data Depperin, selama 2006 total produksi baja hulu nasional (iron making) hanya tercatat 2,5 juta ton dibandingkan kebutuhan ideal yang mencapai 6 juta ton. Sementara itu, total kapasitas produksi baja hilir pada tahun yang sama mencapai 24,4 juta. Saat ini industri yang memanfaatkan produk baja hilir semakin banyak antara lain sektor otomotif, galangan kapal, elektronik dan konstruksi. Namun akibat keterbatasan kapasitas produksi dan juga keterbatasan di bidang teknologi yang dimiliki produsen baja dalam negeri, maka kalangan konsumen industri seperti otomotif dan elektronik lebih memilih mengimpor bahan baku untuk kebutuhan produksinya.
Metoda yang digunakan sebagai dasar untuk merancang sistem adalah menggunakan Model Waterfall sehingga dengan penggunaan metode ini, diharapkan proses analisa dan perancangan sistem ini dapat berjalan dengan baik.

Ada beberapa latar belakang yang mendasari penelitian ini yaitu :

a. Belum tersedianya aplikasi yang memudahkan dalam proses bisnis didalam perusahaan.

b. Proses bisnis yang ada didalam perusahaan selama ini, masih dikerjakan secara manual.

Berdasarkan latar belakang diatas, adapun rumusan masalah pada penelitian ini adalah sebagai berikut :

a. Bagaimana menyediakan informasi dalam jumlah besar dan mudah diakses?

b. Bagaimana meningkatkan efektifitas dan efisiensi orangorang yang bekerja dalam kelompok dalam suatu tempat atau pada beberapa lokasi?

c. Bagaiamana mengotomasikan proses-proses bisnis yang semi otomatis dan tugas-tugas yang dikerjakan secara manual?

\section{METODOLOGI PENELITIAN}

Metode pengumpulan data yang digunakan dalam penelitian ini adalah melalui beberapa proses yaitu :

1. Studi Pustaka

Peneliti melakukan beberapa kajian pustaka terkait dengan isi dari penelitian ini, dengan mengambil beberapa data, baik dari buku-buku maupun jurnal atau sumber yang dapat diambil.

2. Observasi 
Didalam penelitian ini peneliti melakukan observasi di objek atau tempat penelitian. Dengan melakukan pengamatan sistem yang sedang berjalan di perusahaan tersebut dll.

3. Wawancara

Peneliti melakukan beberapa pertanyaan kepada pekerja yang langsung bersentuhan dengan sistem yang sudah ada di perusahaan tersebut.

4. Kuisioner

Peneliti memberikan isian pertanyaan berupa kuisioner kepada pekerja terutama pengguna atau user yang akan menggunakan aplikasi ini, sehingga akan didapatkan hasil tingkat kepuasan dari pengguna aplikasi ini.

Selain itu didalam penelitian ini, di gunakan metode dalam perancangan sistem yang meliputi beberapa tahapan sbb :

1. Analisa Kebutuhan Sistem. Menganalisa data untuk kebutuhan sistem dengan menggunakan analisa yang bersifat membandingkan antara landasan teori yang digunakan dengan obyek.

2. Desain Sistem. Tahapan ini adalah dimana sistem akan dirancang dimulai dari perancangan arsitektur sistem, proses interface, dan interaksi sistem dengan pengguna supaya menghasilkan hasil yang diharapkan.

3. Implementasi. Tahap penerapan sistem agar sistem dapat digunakan dan di operasikan oleh pengguna. Maka di gunakan sebuah bahasa Pemrograman PHP dan SQL sebagai Database.

4. Testing. Tahap ini merupakan tahap ujicoba, dimana pada tahap ini untuk memastikan program dapat berjalan dengan baik dan efektif. Testing yang dilakukan pada program adalah dengan menggunakan Teknik Alpha Method dimana pengujian yang dilakukan hanya untuk mengetahui fungsi - fungsi dalam program yang dapat berjalan dengan lancar.

5. Dokumentasi sistem. Yaitu mendokumentasikan kegiatan dari awal tahapan pengumpulan data sampai dengan kepada implementasi sistem.

\subsection{Implementasi Sistem}

\section{HASIL DAN PEMBAHASAN}

Implementasi merupakan penyajian rangkuman dan cuplikan program inti dari sistem yang dikembangkan berdasarkan hasil perancangan sistem, untuk itu berikut implementasinya yang berupa screen atau tampilan program sistem informasi sales order di PT.ABC Steel :

1. Halaman Log in

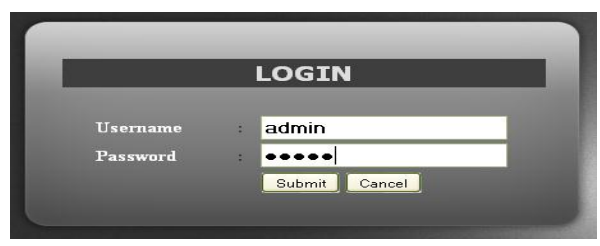

Gambar 1 Halaman Log In
Agar admin maupun user dapat mengakses aplikasi ini, dibutuhkan sebuah halaman Log in yang merupakan halaman yang berfungsi untuk masuk ke dalam semua halaman yang terdapat dalam aplikasi. Tentu saja dengan menginput username dan pasword yang benar. Sebagai sistem keamanan pada aplikasi ini.

2. Halaman Home atau Utama

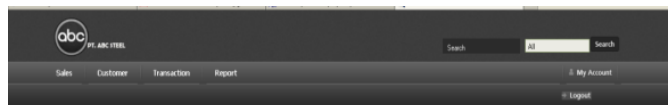

Gambar 2 Halaman Home

Halaman home merupakan halaman yang berfungsi untuk mengakses semua halaman yang terdapat dalam aplikasi. Halaman ini akan tampil apabila admin berhasil login, sehingga admin dapat mengakses halaman yang ada sesuai kebutuhan.

3. Halaman Master Sales

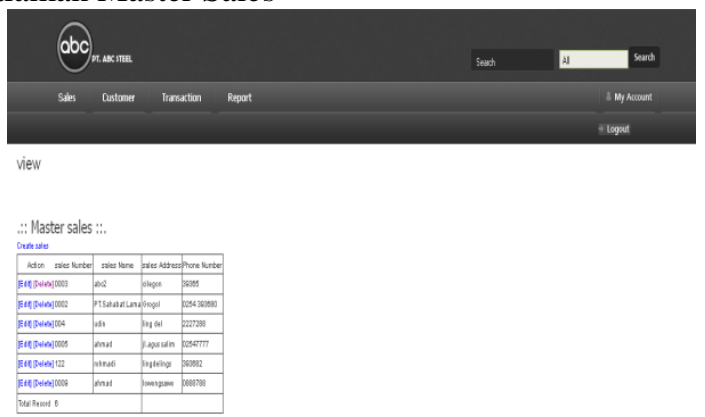

Gambar 3 Halaman Master Sales

Setelah masuk ke halaman home, user bisa masuk ke dalam halaman master sales. Di dalam halaman ini, user dapat mengolah atau memproses atau juga dapat mengelola data. Sesuai yang dibutuhkan. Terutama didalam transaksi penjualan.

4. Halaman Customer / Pelanggan

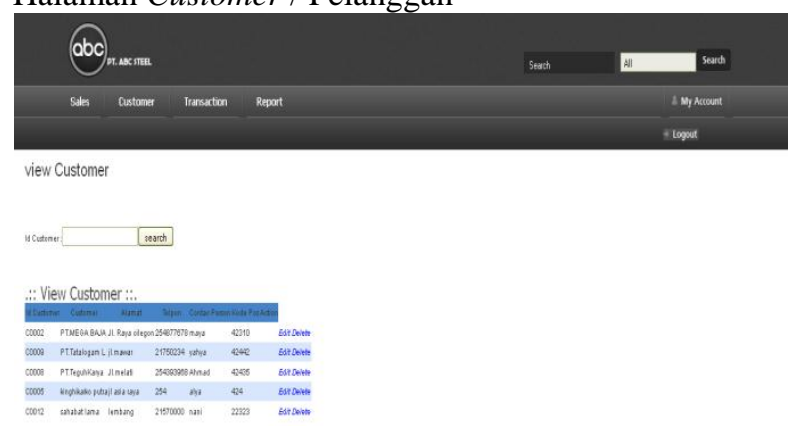

Gambar 4 Halaman Pelanggan 
User ataupun admin di dalam aplikasi ini, dapat melakukan olah data pelanggan. Sehingga di dalam halaman ini. Bisa dilakukan penyimpanan data pelanggan secara sistematis. Agar ketika dibutuhkan masih tersimpan didalam database

5. Halaman Transaksi

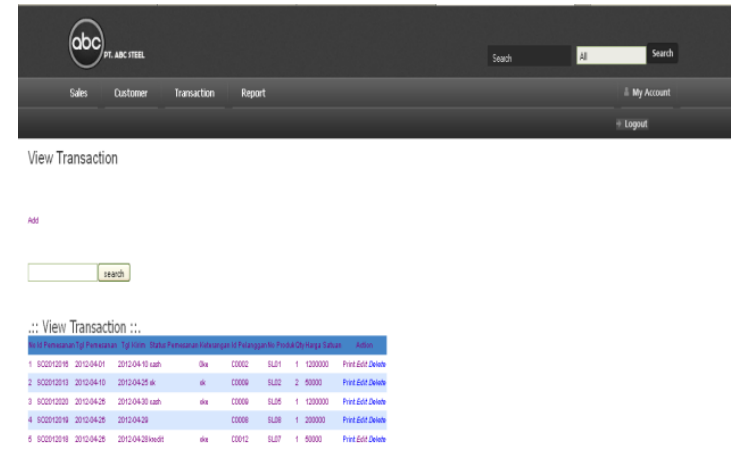

Gambar 5 Halaman Transaksi

Pada halaman ini semua data dari hasil transaksi penjualan di tampilkan, sehingga dapat memudahkan kontrol terhadap setiap proses transaksi yang telah dilakukan

\subsection{Pengujian Sistem}

Pada tahap pengujian sistem atau uji coba aplikasi yang telah dibuat sesuai kebutuhan sistem. Pengujian aplikasi ini adalah dengan menggunakan teknik alpha methode yang tidak berbeda dengan metode blackbox yang sudah umum digunakan didalam pengujian sistem. Prosesnya yang dilakukan dengan cara mengetahui fungsi-fungsi dalam setiap fitur yang ada didalam program, dapat berjalan dengan baik dan lancar.

Tabel 1 Tabel Pengujian

\begin{tabular}{|l|l|c|c|c|}
\hline \multirow{2}{*}{ No } & \multirow{2}{*}{ Item Pengujian } & \multicolumn{2}{|c|}{ Hasil } & \multirow{2}{*}{ Ket } \\
\cline { 3 - 4 } & & Bisa & Tidak & \\
\hline 1 & Form Log in & Ok & & Sesuai \\
\hline 2 & Halaman Home & Ok & & Sesuai \\
\hline 3 & $\begin{array}{l}\text { Hal. Master } \\
\text { Sales }\end{array}$ & Ok & & Sesuai \\
\hline 4 & Hal. Pelanggan & Ok & & Sesuai \\
\hline 5 & $\begin{array}{l}\text { Halaman } \\
\text { Transaksi }\end{array}$ & Ok & & Sesuai \\
\hline
\end{tabular}

\subsection{Sistem Penilaian}

Pengujian sistem sudah dilakukan dengan menggunakan kuisioner, yang disebarkan kepada beberapa pengguna aplikasi dengan menggunakan perhitungan skala likert.

Tabel 2 Kuisioner Aplikasi

\begin{tabular}{|l|l|l|l|l|l|l|l|}
\hline No & Pertanyaan & SS & S & C & TS & STS & TOTAL \\
\hline 1 & $\begin{array}{l}\text { Puaskah anda dg } \\
\text { aplikasi ini? }\end{array}$ & 4 & 3 & 1 & 1 & 1 & 10 \\
\hline 2 & $\begin{array}{l}\text { Puaskah menurut } \\
\text { anda tampilan } \\
\text { aplikasi ini? }\end{array}$ & 5 & 2 & 1 & 1 & 1 & 10 \\
\hline
\end{tabular}

Tabel 3 Bobot Nilai

\begin{tabular}{|c|c|}
\hline A & 5 \\
\hline B & 4 \\
\hline C & 3 \\
\hline D & 2 \\
\hline E & 1 \\
\hline
\end{tabular}

Tabel 4 Tabel Persentase Nilai

\begin{tabular}{|c|c|}
\hline Jawaban & Keterangan \\
\hline $0 \%-19.99 \%$ & $\begin{array}{c}\text { Sangat (Tidak Setuju, Buruk atau Kurang } \\
\text { Sekali) }\end{array}$ \\
\hline $20 \%-39.99 \%$ & Tidak Setuju atau Kurang Baik \\
\hline $40 \%-59.99 \%$ & Cukup \\
\hline $60 \%-79.99 \%$ & Setuju, Baik atau Suka \\
\hline $80 \%-100 \%$ & Sangat (Setuju, Baik, Suka) \\
\hline
\end{tabular}

Dari data yang didapat diatas kemudian diolah dengan cara mengalikan setiap point jawaban dengan bobot yang sudah ditentukan dengan tabel bobot nilai.

Hasil perhitungan jawaban responden sebagai berikut :

Pertanyaan pertama :

1. Responden yg menjawab SS $(5)=4 \times 5=20$

2. Responden yg menjawab $S(4)=3 \times 4=12$

3. Responden yg menjawab $\operatorname{Netral}(3)=1 \times 3=3$

4. Responden yg menjawab $\mathrm{TS}(2)=1 \times 2=2$

5. Responden yg menjawab $\operatorname{STS}(1)=1 \times 1=1$ Total skor $=20+12+3+2+1=38$

Pertanyaan kedua :

1. Responden yg menjawab SS $(5)=5 \times 5=25$

2. Responden yg menjawab $S(4)=2 \times 4=8$

3. Responden yg menjawab $\operatorname{Netral}(3)=1 \times 3=3$

4. Responden yg menjawab $\mathrm{TS}(2)=1 \times 2=2$

5. Responden yg menjawab $\operatorname{STS}(1)=1 \times 1=1$ Total skor $=25+8+3+2+1=39$

Jumlah Skor Pertanyaan $1 \& 2=38+39=77$

Untuk mendapatkan hasil interpretasi, harus diketahui dulu skor tertinggi (X) dan angka terendah (Y) untuk item penilaian dengan rumus sebagai berikut :

$\mathrm{Y}=$ Skor tertinggi likert $\mathrm{x}$ jumlah responden (angka tertinggi 5) "Lihat Bobot Nilai"

$\mathrm{X}=$ Skor terendah likert $\mathrm{x}$ jumlah responden (angka terendah 1) "Lihat Bobot Nilai"

Jumlah Skor tertinggi untuk item SANGAT SETUJU adalah 5 x 17=85 sedangkan Item SANGAT TIDAK SETUJU adalah $1 \times 17=17$.

Jadi, jika total skor responden diperoleh angka 77, maka penilaian interpretasi responden tersebut adalah dengan menggunakan rumus index $\%$

$$
\begin{aligned}
\text { Rumus Index } \% & =\text { Total Skor } / \mathrm{Y} \times 100 \\
& =77 / 85 \times 100 \\
& =90,5 \%=90 \%
\end{aligned}
$$

Masuk ke dalam KATEGORI SANGAT SETUJU 


\section{KESIMPULAN}

Dari pembuatan skripsi Sistem Informasi Sales Order pada PT.ABC Steel serta pengujian terhadap program yang dibuat dapat disimpulkan :

1. Sistem dapat memberikan tampilan informasi berupa data penjualan didalam perusahaan.

2. Hasil Pengujian terhadap rancangan sistem dan basis data serta program telah diterapkan dalam pembuatan sistem informasi sales order dengan menggunakan teknologi berbasis web.

3. Dengan sistem informasi sales order ini, diharapkan dapat meminimalisir Human Error pada saat penginputan data penjualan sales order.

4. Data bisa diorganisir di basis data, diupdate dan diambil oleh petugas sales melalui akses internet.

\section{REFERENSI}

[1] Analisis dan perancangan sistem sales order padaperusahaan,Openstorage.gunadarma.ac.id/Present asi-sidang/FIK-10107593.pptx

[2] Febrian, Jack. (2009). Kamus Komputer dan Teknologi informatika Komputer. Bandung: Penerbit Informatika.

[3] Jogiyanto, HM.(1989). Analisis \& Disain Sistem Informasi: Pendekatan Terstruktur Teori dan Praktek Aplikasi Bisnis. Yogyakarta : Andi

[4] Jogiyanto, HM. (2005). Analisis dan Desain Sistem Informasi. Yogyakarta: Penerbit ANDI

[5] Kurniawan, R. (2008). "Membangun situs dengan PHP untuk orang awam." Palembang. Maxikom

[6] Raharjo, Budi. (2011). Modul Pemrograman Web (Html,Php \& Mysql). Bandung. Penerbit Informatika

[7] Sistem informasi dan teknologi, http://id.wikipedia. org/wiki/Sistem informasi diakses pada bulan Mei 2012. 